\title{
Modeling the structural relationships of internet addiction based on executive functions and problems interpersonal: the mediating role of Alexithymia
}

\author{
Masoume Mohebi ${ }^{1}$, Hassan Asadzade ${ }^{2}$, Noorali Farrokhi ${ }^{3}$ \\ 1-Ph.D Student in Educational Psychology, Department of Educational Psychology, Science and Research Branch, \\ Islamic Azad University, Tehran, Iran. \\ 2- Associate Professor, Department of Educational Psychology, Allameh Tabataba'i University, Tehran, Iran \\ (Corresponding Author). E-mail: Asadzadeh@atu.ac.ir \\ 3- Associate Professor, Department of Evaluting and Measuring, Allameh Tabataba'i University, Tehran, Iran.
}

Received: 23/04/2020

Accepted: 20/06/2020

\begin{abstract}
Introduction: Internet addiction is a type of impulse control disorder that refers to excessive use of the internet and can affect other social activities.

Aim: Purpose of this study was to determine the structural relationships of executive functions, interpersonal problems with internet addiction through the mediation of gossip and excitement.

Method: The descriptive-correlation research method was based on the modeling method of regression structural equations. In order to achieve this goal, out of all seventh grade female students in Tehran's 1, 7 and 8 grades in the 2018-2019 academic year, 260 people were randomly selected as clusters and were referred to the Rescue Executive Function Questionnaire (2013), Barkham, Hardy, \& Startup (1988), intermediate problems, Toronto Gabby, Parker, and Taylor (1994), and Kimberly Young's Internet Addiction Scale (1996). Structural equation statistical method was used to analyze the data. Also, all analyzes were performed using SPSS 24 and Amos 23 software.

Results: The results showed that there was a significant significant direct and negative effect between interpersonal problems with internet addiction and a significant positive and positive effect between executive functions and internet addiction $(\mathrm{P}<0.001)$. Emotional inadequacy of internet addiction had a significant direct and positive effect on students $(\mathrm{P}<0.001)$ and also emotional inadequacy played a mediating role in the relationship between executive functions and interpersonal problems with internet addiction $(\mathrm{P}<0.001)$.
\end{abstract}

Conclusion: Based on the research findings, it can be concluded that the present research model had statistically acceptable fit indicators.

Keywords: Addiction psychiatry, Function activator, International health problems, Alexithymia

How to cite this article : Mohebi M, Asadzade H, Farrokhi N. Modeling the structural relationships of internet addiction based on executive functions and problems interpersonal: the mediating role of Alexithymia. Shenakht Journal of Psychology and Psychiatry. 2020; 7 (3): 150-165 . URL: http://shenakht.muk.ac.ir/article-1-938-en.pdf

Copyright ( 92018 the Author (s). Published by Kurdistan University of Medical Sciences. This is an open access article distributed under the terms of the Creative Commons Attribution-Non Commercial License 4.0 (CCBY-NC), where it is permissible to download, share, remix, transform, and buildup the work provided it is properly cited. The work cannot be used commercially without permission from the journal. 


\title{
مدليابى روابط ساختارى اعتياد به ايتترنت براساس كاركردهاى اجرايى و مشكلات بين فردى: نقش واسطهاى ناتويى هيجانى
}

\author{
معصومه محبى '، حسن اسدزاده'، نورعلى فرخى \\ ا.دانشجوى د كتراى روانشناسى تربيتى، گروه روانشناسى تربيتى، واحد علوم و تحقيقات، دانشگاه آزاد اسلامى، تهران، ايران.

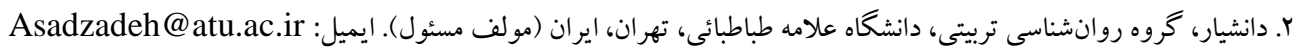

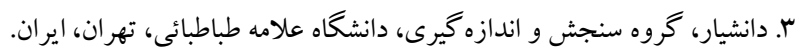

تاريخ هذيرش مقاله: |r/r/raq/

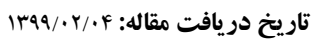

جكکUه

مقدمه: اعتياد به اينترنت نوعى اختلال كنترل تكانه است كه به استفاده بيش از حد از اينترنت اطلاق مىشود و مىتواند ساير فعاليتهاى اجتماعى فرد را تحت تأثير قرار دهد.

هدف: يزوهش حاضر با هدف تعيين روابط ساختارى كاركردهاى اجرايى، مشكلات بين فردى با اعتياد به اينترنت با ميانجى گرى نا نويى هيجانى لنجام شد.

روش: روش ئزوهش توصيفى - همبستگى مبتى بر روش مدل يابى معادلات ساختارى ركرسيونى بود. به منظور دستيابى به اين هدف

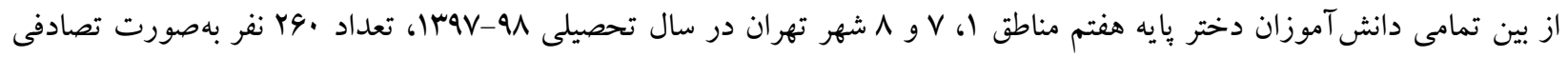

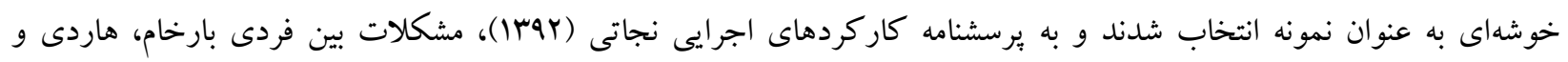

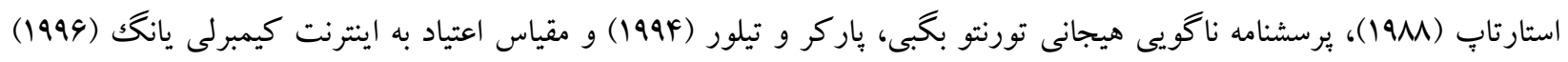

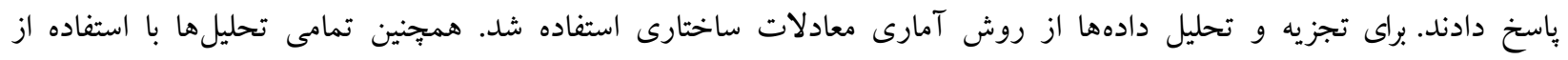

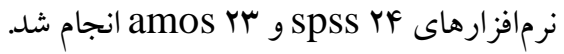

يافته ها: نتايج نشان داد كه بين مشكلات بين فردى با اعتياد به ايترنت اثر مستقيم و منفى معنادار و بين كار كردهاى اجرايى با اعتياد به

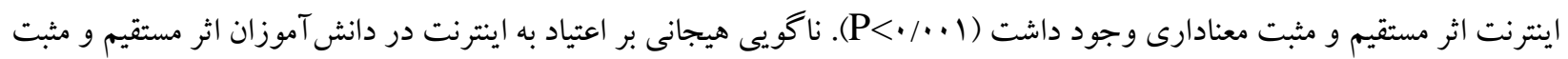

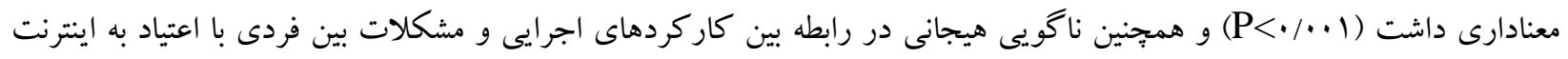

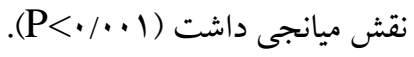

نتيجه كيرى: براساس يافتهاى يزوهش مى توان نتيجه گيرى كرد كه مدل ئزوهش حاضر از نظر آمارى شاخص هاى برازش قابل قبولى داشت. كليدوازهها: كاركردهاى اجرايى، مشكلات بين فردى، ناكويى هيجانى، اعتياد به اينترنت 
روابطى كه بيرامون اينترنت شكل مى گيرند اشكال

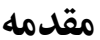
ضعيفى از ارتباطات هستند و بر روابط خانوادگى نيز تأثير منفى دارند. با مطالعه بيشينه يثزوهش در بررسى علت بروز

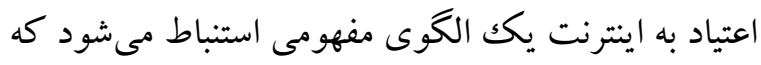
عوامل درون فردى و بين فردى بسيارى مى تو انند بر اعتياد به اينترنت در نوجوانان تأثير بحذارند. مشكلات بين

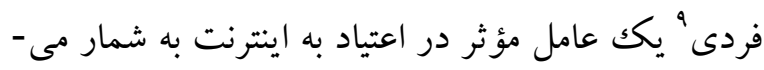
رود. نتايج يزوهشى نشان داد يكى از مهمترين عوامل تأثير كذار بر كرايش به سوى اعتياد به اينترنت، سطح روابط بين فردى است و كرايش به اعتياد به اينترنت زمانى اتفاق مىافتد كه فرد از يكك رابطه بين فردى صحيح برخوردار نبوده و درگير مشكلات بين فردى

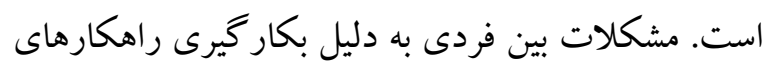
مقابلهاى ناكارآمد به وجود مى آيند كه سبب مقابله

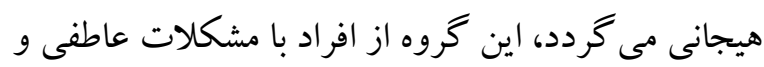
شناختى مواجه هستند و در استفاده از احساسات براى هدايت رفتارشان از جمله هدايت رفتار در محيط هل اجتماعى به طور مناسب، ناتوان هستند؛ بنابراين بيش از افراد عادى امكان بروز رفتارهاى هيجانى نامتعارف دارند

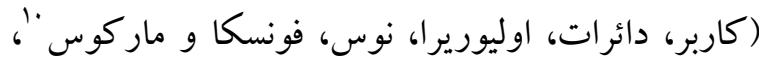

برخى از مشكلات اصلى اين افراد، ناكويى هيجانى "، عدم تنظيم عاطفه، ناكار آمدى در تعامل ميان سيستمها و در تعامل بين سيستم بِاسخ هيجانى و محيط است. اين افراد با طيف وسيعى از مشكلات روانى همجيون اختلال

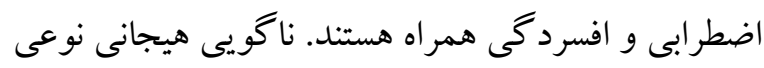

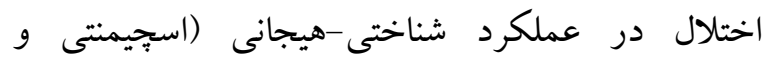

9- Problems Interpersonal

${ }^{10}$ - Carbal, Daurat, Oliverira, Neves, Fonseca \& Marques

${ }^{11}$ - Alexithymia

- Internet Addiction Disorder (IAD)

2- Pathological Internet Use (PIU)

${ }^{3}$ - Zonglin, Xiaoliang, Jingyu, Hosameldin, Ahmed \& Asoke

4- Sariyska, Lachmann, Markett, Reuter \& Montag

5 - Griffiths

${ }^{6}$ - Chen, Chen \& Gau

7. Wu, Ko, Wong, Wu \& Oei

8 - Tang, Chen, Yang, Chung \& Lee 


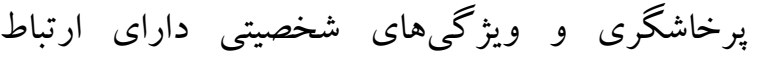

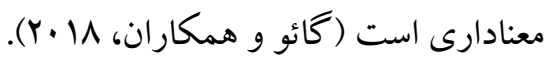
از ديد عصبشناختى يكى از فرايندهاى شناختى و و فراشناختى كه به افراد كمكك مى كند تا به جنبههاى مهم تكليف توجه و براى به بايان رساندن آن برنامهريزى

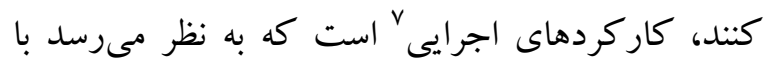
اعتياد به اينترنت، رابطه دارد. كاركردهاى اجرايى مجموعهاى از توانايىهاى برتر سازماندهى و يكهيارجهسازى هستند كه در سطح عصبى-آناتوميكى با مسيرهاى مختلف تعامل عصبى همجيون قشر بيش ييشانى در ارتباط بوده (لو و حال؛، Y.IV) و شامل بيشبينى و ايجاد اهداف، برنامهريزى، خودتنظيمى و نظارت بر اهداف، اجرا و بازخورد مؤثر برنامهها، حافظه كارى و غيره مى شوند كه براى فعاليت مستقل، هدفمند و ساز گارى

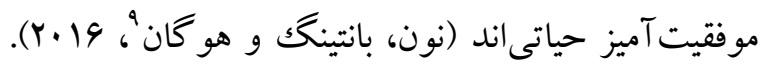
كاركردهاى اجرايى را مىتوان به عنوان شاخص انجام

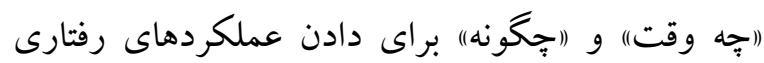
عادى توصيف كرد كه به افراد براى برنامهريزى، اهداف، خود گردانى، بازدارى ياسخ نامناسب، انعطاف يذيرى و و

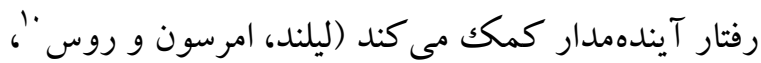

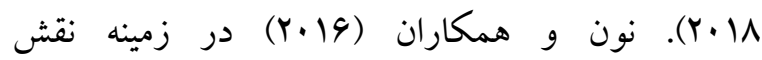
كاركردهاى اجرايى در تنظيم هيجانى نوجوانان به اين نتيجه رسيدند كه كاركردهاى اجرايى بهتر، استفاده از ارزيابىهاى تازه را براى نوجوانان تسهيل مى كند و نوجوانانى كه بر ارزيابى تازه تكيه مى كنند، منبع شناختى بيشترى را براى كمكك به توجه يايدار خود فراهم مى كنند

7- Executive Function

8 - Luu \& Hall

9- Noone, Bunting \& Hogan

${ }^{10}$ - Leyland, Emerson \& Rowse

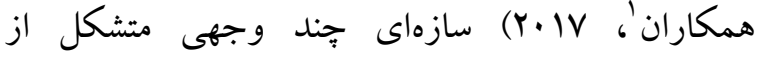
دشوارى در شناسايى احساسات و تمايز بين احساسات و تهييج هاى بدنى مربوط به برانگيختخى هيجانى، دشوارى در توصيف احساسات براى ديخران، قدرت تجسم محدود كه بر حسب فقر خياليردازىها (شامل: سبكشناختى عينى (غيرتجسمى)، عمل گرا و واقعيتمحور يا تفكر عينى) مشخص مىشود (لايورز، كارانتونيز، ادوارد

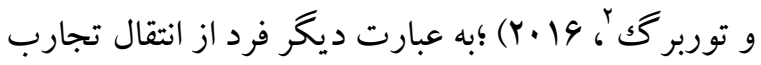
هيجانى خود در قالب احساسات و تصورات ناتوان است (اسجيمنتى و همكاران، Y.IV). استنسيرى، والاستيرو و كروتيف " (Y) (Y) در مطالعهاى دريافتند كه افراد مبتلا به واله ناكويى هيجانى، تهييجهاى بدنى بهنجار را بزرگك كرده، نشانهاى بدنى انخيختخى هيجانى را بد تفسير مى كنند.

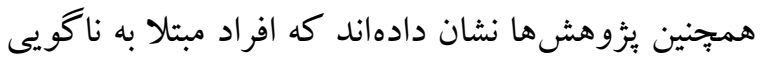
هيجانى در شناسايى صحيح هيجانها و نيز در روابط اجتماعى مشكل دارند و سبب دورى گزينى آنان مى گردد

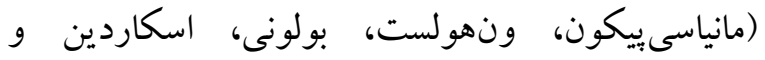

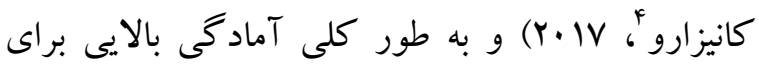

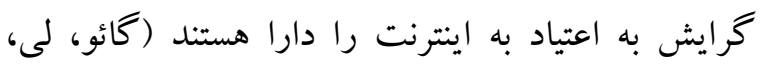

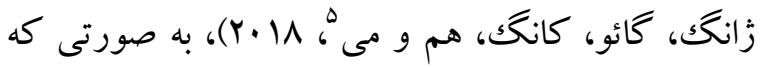
فرد تمايل به ارتباط دارد؛ اما با توجه به نقايص هبردازش هيجانى به سوى فضاى اينترنتى گرايش بيدا مىنمايد

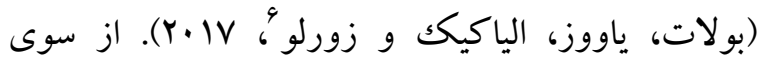
ديخر نتايج يزوهشها نشان دادهاند كه اعتياد به اينترنت با لـان عزتنفس و روابط اجتماعى پياين، روابط حمايت

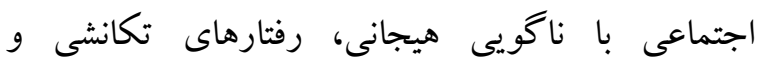

\footnotetext{
1. Schimmenti \& et al

2 - Lyvers, Karantonis, Edwards \& Thorberg

3 - Spensieri, Valastro \& Cerutti

${ }^{4}$ - Maniaci, Picone, Van Holst, Bolloni, Scardina \& Cannizzaro

5- Gao, Li, Zhang, Gao, Kong, Hu \& Mei

${ }^{6}$ - Bolat, Yavuz, Eliaçık \& Zorlu
} 
نفر از دانشآموزان به روش تصادفى خوشهاى انتخاب شدند. در اين بثزوهش معيارهاى ورود آزمودنىها به آنه مطالعه شامل؛ دانش آموز دختر بايه هفتم، ساكن مناطق له له V و 1 تهران، علاقهمند به همكارى در بئوهش و فاقد هركونه بيمارى روانى بود. همجِنين معيارهاى خروج شامل؛ عدم همكارى در بُزوهش و داشتن بيمارى بود. بس از انتخاب گروه نمونه به صورت تصادفى، برسشنامه ها با رعايت اصول اخلاقى بثوهش از جمله؛ رضايت

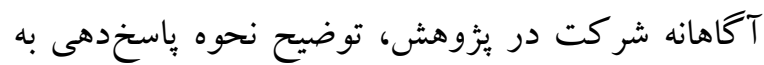
سؤالها و ضرورت همكارى صادقانه، حسن رفتار و محرمانه ماندن اطلاعات، خروج از يزوهش در صورت عدم تمايل به ادامه همكارى، اجتناب از تحريف دادهها و دادهازى، در بين دانش آموزان توزيع شد. همجنين در لهر اين يزوهش جهت تجزيه و تحليل دادهها از مدليابى معادلات ساختارى و نرمافزارهاى SPSS Y و r M

|ستفاده شد.

ابزار به منظور جمع آورى دادههاى مورد نياز از يرسشنامهاى شرح زير استفاده شد:

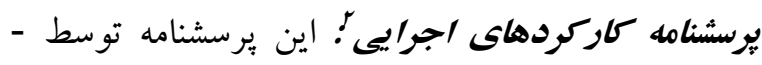
نجاتى (Y (Ir) تهيه شده و شامل •r ماده و Vزير مقياس؛ حافظه، بازدارى، توجه انتخاب، تصميم گيرى، برنامهريزى، توجه يايدار، شناخت اجتماعى و انعطافيذيرى شناختى است. ياسخگ اي ليكرت تنظيم شده است و به هر سؤال ا تا ها نمره تعلق مى گيرد. در مقياس شناخت اجتماعى نمره گذارى به طور معكوس انجام مىشود. ضريب آلفاى كرونباخ

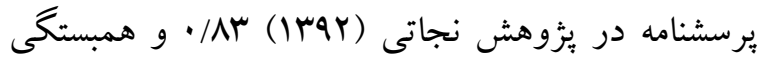

${ }^{2}$ - Executive Performance Questionnaire
كه به تنظيم بهتر هيجاناتشان در زندگى روزمره شان منجر

$$
\text { مى شود. }
$$
با توجه به مطالب كفته شده در بالا مىتوان كفت كه اعتياد به اينترنت اختلالى است كه موجب بريشانى و نقصهاى كاركردى و ايجاد مشكلات روانشناختى، اجتماعى، تحصيلى و كارى (انزوا، نمرات يايين، اختلاف با ديخران) مىشود كه نشان از وجود آسيب جدى به له دانش آموزان است و در نتيجه آن، جامعه نيز بايد هزينههاى زيادى به منظور كاهش مشكلات ياد شده متحمل شود. لذا انجام يزوهشهاى لازم در راستاى شناسايى عوامل مؤثر بر اعتياد به اينترنت و ارائه راهكارهايى در جهت سلامت نوجوانان شواهدى به دست مىدهد كه با تكيه بر آنها و هدف قرار دادن آنها، مىتوان برخى از اين مشكلات را برطرف نمود. از اين رو سؤال اصلى در يثزوهش حاضر اين است كه آيا مدل ييشبينى اعتياد به اينترنت بر اساس كار كرد اجرايى، مشكلات بين فردى با ميانجى گرى نقش ناگويى هيجانى در دانش آموزان داراى

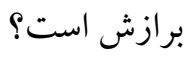

\section{روش}

يثوهش حاضر، از نوع توصيفى-همبستكى مبتنى بر روش مدل يابى معادلات ساختارى رگرسيونى بود. تمامى دانش آموزان مدارس دخترانه كه در سال تحصيلى

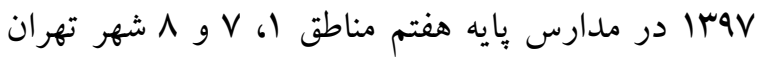
مشغول به تحصيل بودند جزو جامعه آمارى بثوهش بود. يس از تعيين حجم نمونه با روش برآورد حجم لوهلين' كه به ازاى هر متغير ينهان بين ·r (Y.F)

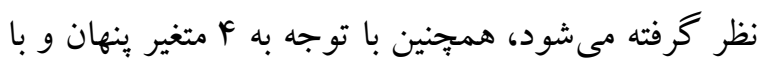
rq. احتساب احتمال وجود يرسشنامهاى ناقص، تعداد

\footnotetext{
1. Lvhlyn
} 
11 و 19 به صورت معكوس نمره كذارى شده و از جمع نمرههاى زيرمقياسها، نمره كلى ناگويى هيجانى محاسبه مىشود. اين مقياس براى اجرا در نمونههاى عمومى و بالينى مناسب است و مىتواند برحسب شر ايط به صورت فردى يا گروهى اجرا شود. بخَى و همكاران (1994) يايايى ابزار مذكور را با استفاده از ضريب آلفاى كرونباخ

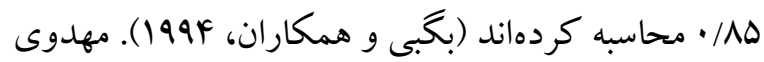
و منشئى (هوس ا) نيز و يايايى اين برسشنامه را با استفاده از ضريب آلفاى كرونباخ V9/. گز ارش كردهاند كه نشانه همسانى درونى مطلوب آن است (مهدوى و منشئى،

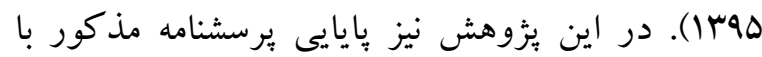
استفاده از ضريب آلفاى كرونباخ MA/ • محاسبه شد.

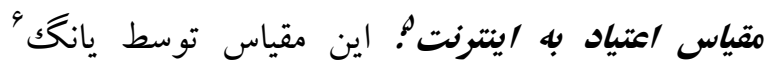
(1999) تهيه شده و شامل ·r سؤال است كه اعتياد به اينترنت را در ه عامل؛ مشكلات اجتماعى، تأثير بر عملكرد، فقدان كنترل، استفاده از جت، بىتوجهى به شغل و وظايف مورد بررسى قرار مىدهد. باسخ به سؤ ال-

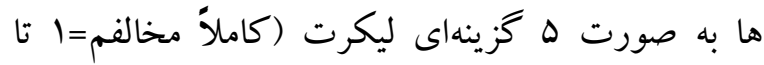
كاملاً موافقم=ها ) طراحى شده است. روايى وبرسشنامه اعتياد به اينترنت توسط سازندگان آن مورد تأييد قرار كرفت. در بزّوهش يانگگ (1999) بايايى مقياس با استفاده از ضريب آلفاى كرونباخ در ه عامل؛ مشكلات

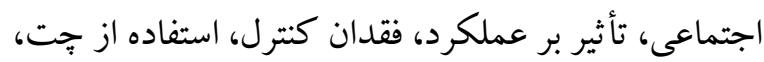

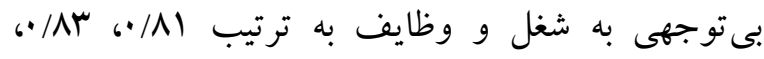

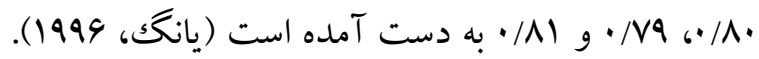
در ايران نيز در يُزوهش علوى، جنتىفرد، اسلامى و

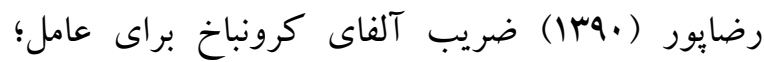
مشكلات اجتماعى 1//•، تأثير بر عملكرد سل/ •، فقدان

5. Young Internet Addiction Test

6- Young

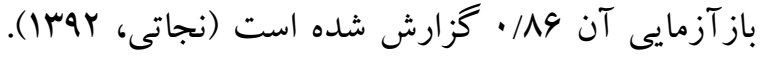
در يزوهش توصيفيان، قادرى بگهذجان، محمودى و خالديان (وهس|) نيز ضريب آلفاى كرونباخ ه内/ • گزارش شد (توصيفيان و همكاران، و وبا). در اين يثوهش نيز پايايى : برسشنامه مذكور با استفاده از ضريب آلفاى كرونباخ •1// • محاسبه شد. يرسشنامه مشكلات بينفردى'؛ اين برسشنامه توسط

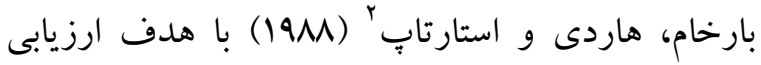

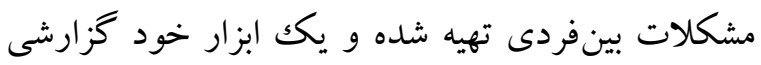
كه داراى بr سؤال و 9 عامل؛ صراحت و مردم آميزى،

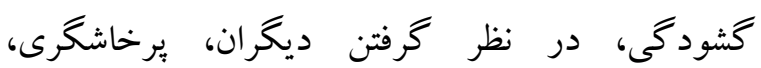
حمايتخرى و مشاركت و وابستخى هست. ياسخكويى به

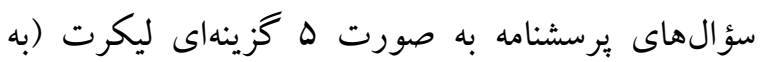
شدت=ه تا به هيج وجه=|() تنظيم شده است و به هر سؤال ا تا ها نمره تعلق مى گيرد. ضريب آلفاى كرونباخ

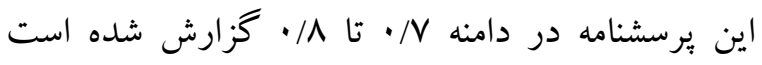

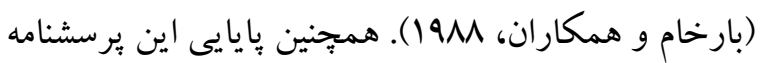
در ايران توسط آزاد فلاح (rar) با استفاده از ضريب

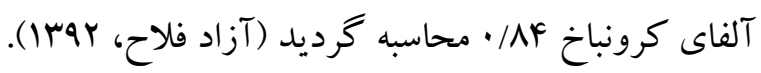
در اين هُوهش نيز بايايى برسشنامه مذكور با استفاده از ضريب آلفاى كرونباخ V9/ • محاسبه شد. يرسشنامه ناكويح هيجانى توزنتوّ" اين برسشنامه توسط

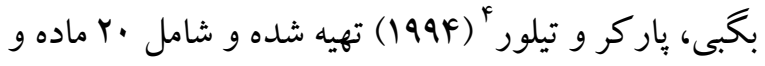
سه زير مقياس؛ دشوارى در شناسايى احساسات، دشوارى در توصيف احساسات و تفكر عينى است. ياسخكويى به

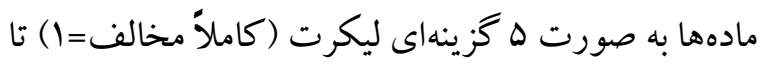

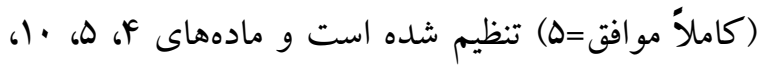

\footnotetext{
1- Inventory of Interpersonal Problems

2 - Barkham, Hatdy \& Startup

3. Toronto Alexithymia Scale

4- Bagby, Parker \& Taylor
} 


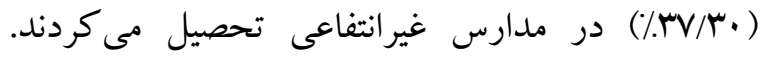
همجنين تعداد |F| نفر (سF/هF/\%) در مدارس نوبت صبح و تعداد 19 انفر (F/VVV) نفر نيز در مدارس نوبت بعد از ظهر مشغول به تحصيل بودند.

شاخصهاى توصيفى مربوط به مشكلات بينفردى، كاركردهاى اجتماعى، اعتياد به اينترنت و ناكويى هيجانى در جدول ا گزارش شده است.

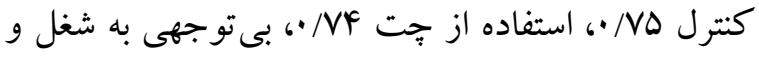

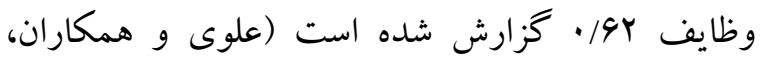

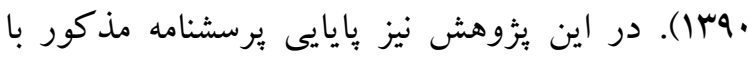
استفاده از ضريب آلفاى كرونباخ ·V/ • محاسبه شد.

\section{يافته ها}

آزمودنى هاى اين بثزوهش را دانش آموزان دختر متوسطه اول تشكيل دادند كه ميانخين سن آنها بود. تعداد •19 نفر ( • (9Y/V) در مدارس دولتى و 9V نفر

\section{جدول ا شاخص هاى توصيفى متغير هاى يزوهش در دانش آموزان تروه نمونه}

\begin{tabular}{|c|c|c|}
\hline 19/rr & $11 \cdot / \Delta r$ & مشكلات بينفردى \\
\hline$Q / \vee \Delta$ & $\Lambda q / F \Delta$ & كار كردهاى اجرايى \\
\hline $1 \cdot / \Lambda \Delta$ & $r q / 11$ & اعتياد به اينترنت \\
\hline $1 . / 4 \pi$ & $9 . / 9$. & ناكويى هيجانى \\
\hline
\end{tabular}

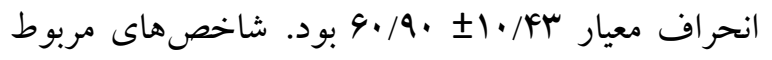

به برازش حاصل از تجزيه و تحليل دادهها در جدول كزارش شده است.
نتايج جدول ا نشان داد كه متغير مشكلات بين فردى

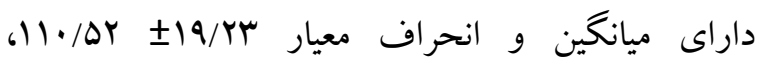
كاركردهاى اجرايى AQ/FD IQ/VD، اعتياد به اينترنت

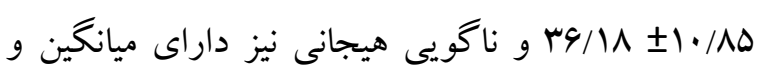

\begin{tabular}{|c|c|c|c|c|}
\hline نتيجه كيرى & مقادير به دست & مقادير مطلوب & شاخصهاى نيكويى برازش & شاخص \\
\hline- & DSV/DYG & Nil & آزمون نيكويى برازش مجذور كاى & \multirow{3}{*}{ 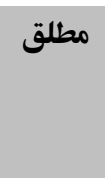 } \\
\hline برازش قابل قبول &.$/ 994$ & 2.9 & شاخص نيكويى برازش & \\
\hline برازش قابل قبول &.$/ 91 \mathrm{~V}$ & .2 .9$. & شاخص نيكويى برازش تعديل شده & \\
\hline برازش قابل قبول &.$/ 994$ & 2.9 & شاخص استاندارد شده برازش & \multirow[t]{4}{*}{ تطبيقى } \\
\hline برازش قابل قبول &.$/ 9 \Delta V$ & 2.9 & شاخص برازش تطبيقى & \\
\hline برازش قابل قبول & $\cdot / 9 k Y$ & .2 .9 & شاخص برازش تطبيقى & \\
\hline برازش قابل قبول & $\cdot / 9 V$ & 2.9 & شاخص برازش نسبى & \\
\hline برازش قابل قبول & $\cdot / \Delta r \mid$ & $\cdot / 0.5$ & شاخص برازش هنجارشده & \multirow[t]{2}{*}{ مقتصد } \\
\hline برازش قابل قبول & $\% \kappa r$ & $\cdot / \cdot \wedge \geq$ & ريشه خطاى ميانكين مجذورات تقريب & \\
\hline
\end{tabular}




\begin{tabular}{|c|c|c|c|}
\hline برازش قابل قبول & Y/QYF & $r \geq$. & نسبت مجذور كاى به درجات آزادى \\
\hline- & 194 & $\cdot \leq$ & درجه آزادى \\
\hline برازش قابل قبول & $\cdot \cdots$ & $\cdot / \cdot \Delta \geq$ & 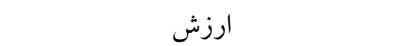 \\
\hline
\end{tabular}

مقادير اثر (B) آمارههاى وزنى رگرسيونى (با توجه به سطح معنادارى به دست آمده از نسبت بحرانى) در جدول بارائه شده است.
آمارههاى به دست آمده از شاخص هاى تطبيقى، مطلق و مقتصد در جدول r نشان داد كه مدل به دست آمده

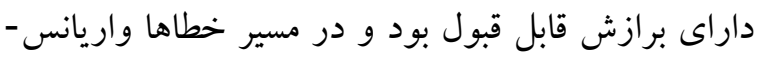
هاى به دست آمده صحيح بود. اطلاعات مربوط به تعيين
يكديگر را با توجه به مقدار t به دست آمده در مدل نشان مى دهد كه تمامى مقادير به دست آمده معنادار بودند و نشان دهنده بيشبينى معنادار بود. اطلاعات مربوط به برآورد غير مستقيم مدل با استفاده از روش بوت استرب در جدول F ار ائه شده است.
با توجه به يافتهاى جدول آ، مقادير خرده مقياسها بر متغير كلى و متغير برونزا (مشكلات بين فردى، كاركردهاى اجرايى و ناكويى هيجانى) بر متغير درونزاى نهايى (اعتياد به اينترنت) اثر معنادار داشت؛ به عبارت ديخر مقادير استاندارد شده و استاندارد نشده، مسيرهاى ييشبينى متغيرهاى يزوهش برونزا بر متغير درونزا با

\begin{tabular}{|c|c|c|c|c|}
\hline معنادارى & حدبالا & حديايين & $\mathbf{B}$ & متغير \\
\hline$\cdot / \cdots$ & .1941 & - / FAY & $\cdot / \Delta V F$ & مشكلات بينفردى \\
\hline$\cdot / \cdots$ & .1941 & $\cdot / 4 \mid r$ & $\cdot / \Delta Q F$ & كار كردهاى اجرايى \\
\hline
\end{tabular}

استفاده از روش بر آورد بوت استرٍ مورد تأييد واقع نتايج جدول F نشان داد مسيرهاى غير مستقيم در نظر كرديد. كرفته شده با توجه به مقادير استاندارد شده به دست آمده، مسير غير مستقيم، مشكلات بين فردى و و كاركردهاى اجرايى با نقش واسطهاى ناكويى هيجانى با 
مخ هم در افراد معتاد به اينترنت كاهش يافته است (زو،

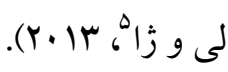

مسير دوم نشان داد كه مشكلات بين فردى با اعتياد به اينترنت در دانشآموزان، داراى اثر مستقيم و مثبت

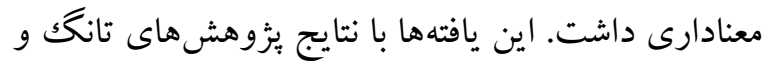

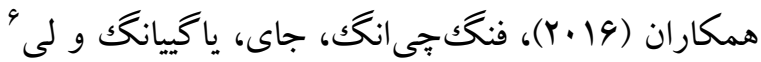

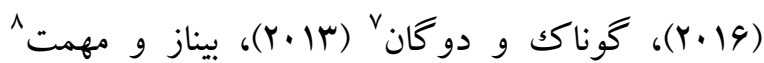

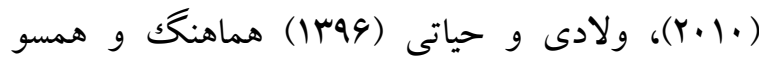
است. در تبيين يافته به دست آمده مىتوان به نتايج برخى بثزوهشها اشاره كرد كه ارتباط اعتياد به اينترنت را از ديد مشكلات بين فردى و صفات شخصيتى در بين كاربران اينترنت بررسى و تأييد كردند (موريو، لاكونى،

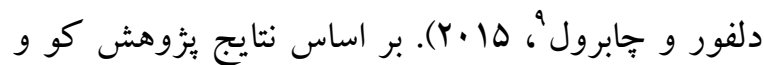
كان" ' (Y.|F) مشكلات بين فردى مانند اضطراب اجتماعى /كمرويى و شايستخى اجتماعى ضعيف با اعتياد به اينترنت رابطه مثبت دارند. يثزوهشهايى كه به بررسى

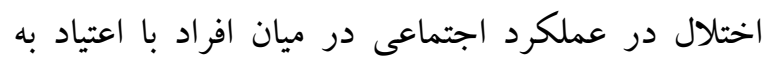
اينترنت برداختهاند، نشان دادهاند افراد معتاد به اينترنت نشانهاى روانيزشكى بيشترى از جمله ناراحتى و ملال، افسردگى، اضطراب، استرس، خصومت و خشم، ترس روسى

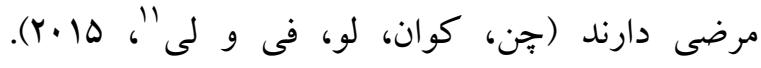
كاربران معتاد نسبت به كاربران غير معتاد از مهارتهاى اجتماعى ضعيفتر و رفتارهاى اجتماعى نامناسبتر و

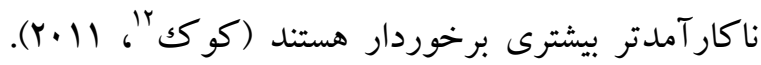
نتايج يزوهشى ديخرى نيز نشان داد كه افراد با ثبات

5- Zhou, Li\&Zhu

6 - Fengqiang, Jie, Yueqiang \& Lei

7. Gunuc \& Dogan

8 - Binnaz \& Mehmet

9 - Moreau, Laconi, Delfour \& Chabrol

${ }^{10}$ - Koo \& Kwon

${ }^{11}$ - Chen, Quan, Lu, Fei \& Li

12 - Koc
اين يثوهش با هدف مدليابى روابط ساختارى اعتياد به اينترنت بر اساس كاركردهاى اجرايى و مشكلات بين فردى: نقش واسطهاى ناگويى هيجانى انجام شد. نتايج تحليل شاخصهاى برازندگى مدل نشان داد كه مدل تدوين شده اعتياد به اينترنت براساس متغيرهاى كاركردهاى اجرايى و مشكلات بين فردى به عنوان متغيرهاى بيشبين و در تعامل واسطه با متغير ناكويى هيجانى از برازش مطلوب برخوردار بود. مدل برازش يافته يزوهش حاضر در مسيرهاى زير قابل تبين و ييشبينى كننده راهكارهايى در جهت ارتقاى سلامت دانش -

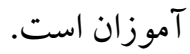
مسير نخست نشان داد كه بين كاركردهاى اجرايى با اعتياد به اينترنت در دانش آموزان اثر مستقيم و منفى معنادار وجود داشت. اين يافته با نتايج يثوهش هاى لين،

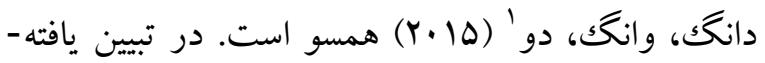
هاى به دست آمده از اين فرضيه مىتوان گفت؛ يكى از ويز گى هاى اعتياد به اينترنت، از دست دادن خود كنترلى در رفتار است. كاركردهاى اجرايى افراد را قادر مىسازد تا تمايلات خود را بازدارى كرده و رفتارهاى مربوط به خوشى و لذت را تحت شرايط نامطلوب محدود سازند

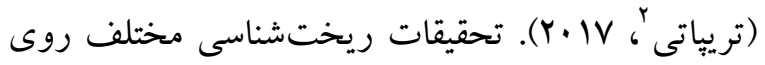
مراكز قشر مخ مغز افراد با اعتياد به اينترنت جندين مكانيسم عصبى را يافتهاند. مناطق مغزى كه در كنترل اجرايى نقش دارند مثل قشر اوربيتوفرونتال، قشر بيش-

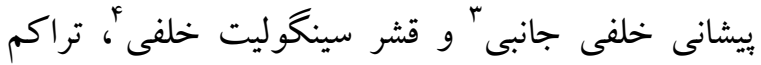
بإيين ماده خاكسترى مغز را نشان مىدهند و ضخامت قشر

\footnotetext{
1- Lin, Dong, Wang \& Du

2 - Tripathi

${ }^{3}$ - Lateral-posterior prefrontal

4 - Posterior Cingular
} 
مسير جهارم نشان داد كه ناگويى هيجانى در رابطه بين كاركردهاى اجرايى با اعتياد به اينترنت نقش ميانجى

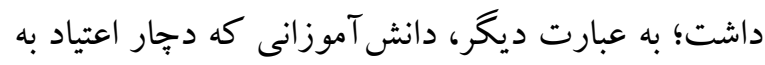
اينترنت مىشوند در صورتى كه مشخصه كاى ناگويى هيجانى و كاركردهاى اجرايى بيشترى داشته باشند، به احتمال زيادترى وابسته به اينترنت مىشوند. يافتهاى عصبشناختى رشدى نيز تأييد مى كنند كه تنظيم هيجان و كاركردهاى اجرايى به صورت غيرمستقيم به هم مرتبط هستند و براى تحليل اطلاعات و اجراى فعاليتها،

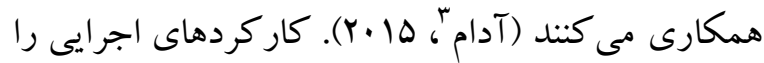

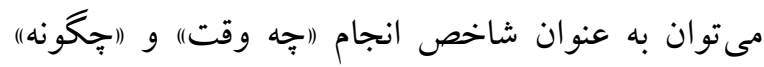
براى دادن عملكردهاى رفتارى عادى توصيف كرد كه به دانش آموزان براى برنامهريزى، اهداف، خود خردانى، بازدارى ياسخ نامناسب، انعطاف يذيرى و رفتار آينده مدار

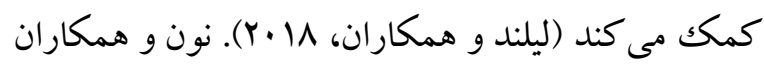
(Y.19) در زمينه نقش كاركردهاى اجرايى در تنظيم هيجانى نوجوانان به اين نتيجه رسيدند كه كاركردهاى اجرايى بهتر، استفاده از ارزيابىهاى تازه را براى نوجوانان تسهيل مى كند و نوجوانانى كه بر ارزيابى تازه تكيه مى كنند، منبع شناختى بيشترى را براى كمكك به توجه بايدار خود فراهم مى كنند كه به تنظيم بهتر هيجاناتشان در

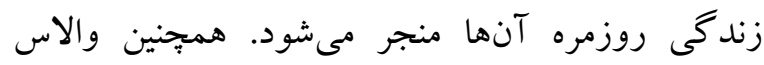

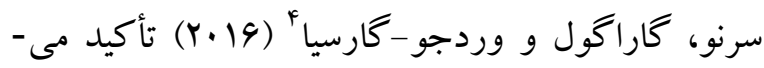
كنند كه رشد تنظيم هيجانى به طور قوى به وسيله جندين هسته از كاركردهاى اجرايى از قبيل؛ كنترل توجه، بازدارى رفتار نامناسب، تصميم گيرى و ديكر فرايندهاى شناختى سطح بالا، حمايت مىشود. جنبه ديخر اعتياد به اينترنت، تأثير بالقوه كار كردهاى اجرايى ضعيف و كنترل

3. Adams

4. Valls-Serrano, Caracuel \& Verdejo-Garcia
عاطفى، هيجانهاى منفى كمترى را تجربه مى كنند و كم تر احتمال دارد كه براى كاهش هيجانهاى منفى به استفاده افراطى و وسواسى از اينترنت بيردازند (جن، جن

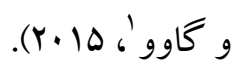
مسير سوم نشان داد كه ناكويى هيجانى بر اعتياد به اينترنت در دانشآموزان، اثر مستقيم و مثبت معنادارى داشت. اين يافته با نتايج يزوهشهاى كايو و همكاران (Y.11) همسو است. در تبيين يافته به دست آمده مى توان جنين استباط نمود كه ويزگىهاى افراد ناكويى هيجانى، منعكس كننده نقايصى هم در حيطه شناختى-تجربى باسخ هيجانى و هم در سطح تنظيم هيجان بين فردى است، ناتوانى در شناسايى دقيق احساسات، ضعف زياد در انتقال كلامى درماندگىهاى هيجانى به ديخران، شكست در كمك كرفتن از ديخران امكان بروز رفتارهاى نابهنجار در اثر زندگى مستمر با ديخران را

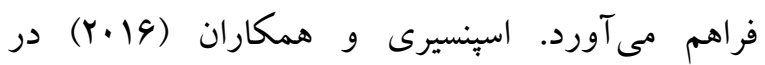
يثزوهشى دريافتند كه افراد مبتلا به ناكويى هيجانى،

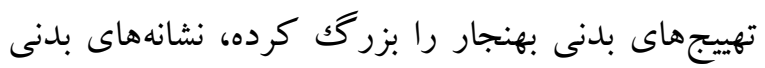

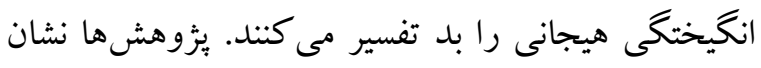
دادهاند كه افراد مبتلا به ناكويى هيجانى در شناسايى صحيح هيجانها و در روابط اجتماعى مشكل دارند كه سبب دورى گزينى آنان مى گردد (مانياسى و همكاران،

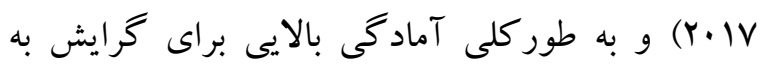

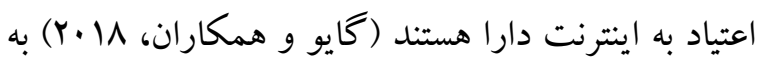
صورتى كه فرد تمايل به ارتباط دارد؛ اما با توجه به نقايص بردازش هيجانى به سوى فضاى اينترنتى گرايش

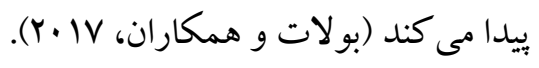

\footnotetext{
1. Chen, Chen \& Gau

${ }^{2}$ - Alpaslan, Avci \& Guzel
} 
نيز اشاره كرد، آنها دريافتند كه افراد مبتلا به ناكويى هيجانى با تحريف تهييجهاى بلنى بهنجار، نشانهاى بدنى

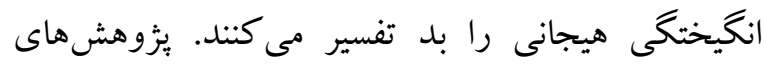
ديخر نيز نشان مىدهند كه افراد مبتلا به ناكويى هيجانى در شناسايى صحيح هيجانها و روابط اجتماعى دجار

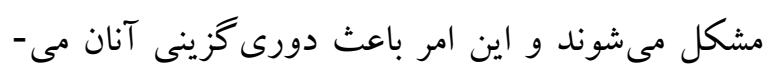
شود. اين افراد به طور كلى آمادكى زياد براى اعتياد به إنه

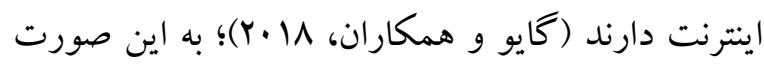
كه فرد تمايل به ارتباط دارد؛ اما با توجه به نقايص بردازش هيجانى به فضاى اينترنتى كرايش بيدا مى كند

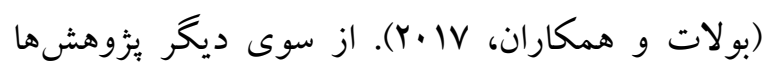

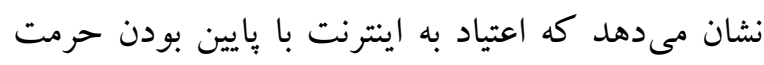
خود و ضعف در برقرارى روابط اجتماعى (بولات و و

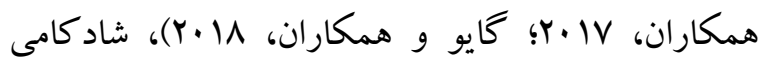
(رستخار، عبدالهى و شاه قليان، سهبا)، زياد بودن

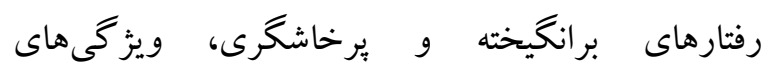
شخصيتى، استفاده نكردن از راهبردهاى مقابلهاى مناسب

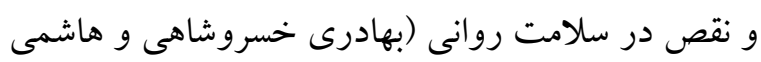
نصرت آباد، •وسו ) ارتباط معنادار دارد.

\section{نتيجه كيرى}

به طور كلى نتايج يثوهش نشان داد كه مدل ئزوهش حاضر از نظر آمارى داراى شاخصهاى برازش قابل قبولى داشت. در نتيجه دادههاى به دست آمده از مدل از يثوهش حاضر حمايت كردند. روابط حاكم بين مسيرهاى مدل نشان داد كه كاركردهاى اجرايى و و مشكلات بين فردى در كنار هم به عنوان مهمترين عوامل در ييشبينى اعتياد به اينترنت نقش داشتند. همجنين نتايج نشان داد كه جِخونه متغير ناكويى هيجانى در نقش متغير
بازدارى ضعيف است. كاركردهاى اجرايى به ويزه

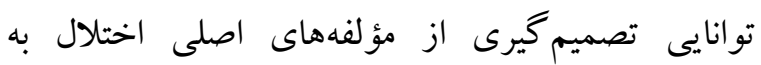
اينترنت محسوب مىشود (دانگك و يوتنز '، Y. Y. Y). مسير وِنجم نشان داد كه ناگويى هيجانى در رابطه بين

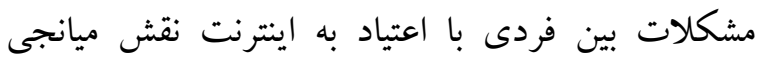
داشت؛ يعنى دانش آموزانى كه دجار اعتياد به اينترنت مىشوند در صورتى كه مشخصههاى ناكويى هيجانى و نشانهاى مشكلات بينفردى بيشترى داشته باشند، به احتمال زيادترى وابسته به اينترنت مىشوند. اين يافته همسو با نتايج يزوهش هاى (مانياسى، بيكون، وانهولست،

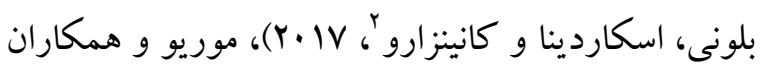

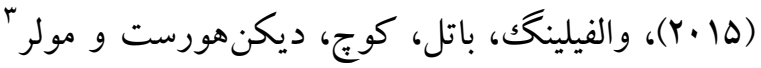

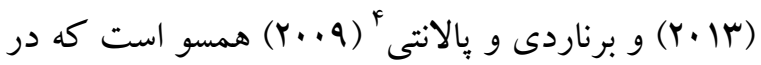
تبيين اعتياد به اينترنت، مشكلات بينفردى را برجسته ساختهاند. در تبيين نقش ميانجى ناكويى هيجانى در رابطه بئه

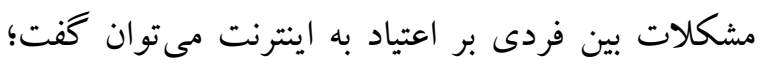
مديريت مناسب ابراز و القاى هيجانات توسط فرد هنگامى كه در شرايط يرفشار قرار دارد، توان شناخت بهتر در شرايط متفاوت را ايجاد مى كند، بنابر اين فشارهاى محيطى كمترى دريافت مى كند و عملكردش بهبود مى -

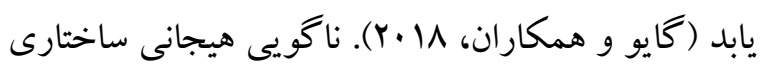

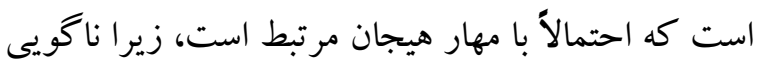
هيجانى، ناتوانى در ابراز هيجان به دليل نقص در توانايى

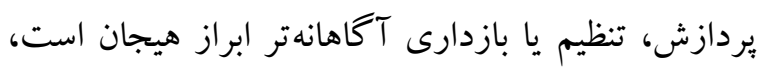

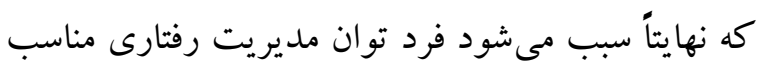

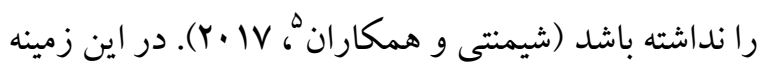

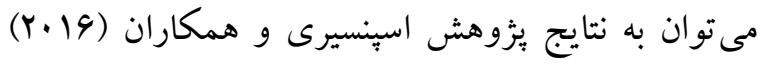

\footnotetext{
1- Dong \& Potenza

2- Maniaci, Picone, Van Holst, Bolloni, Scardina \& Cannizzaro

3. Wolfling, Beutel, Koch, Dickenhorst \& Muller

4- Bernardi \& Pallanty

5 - Schimmenti \& et al
} 
Azadfallah P. (2013). Validity and Reliability of Interpersonal Problems Questionnaire. Joumal of Clinical Psychology, 5(3): 69-82. [Persian].

Bagby RM, Parker JDA, Taylor GJ. (1994). The twenty-item Toronto Alexithymia scale-I. Item selection and cross-validation of the fac tor structure. Joumal of Psycho Somatic Research, 38(1): 23-32. doi:10.1016/00223999(94)90005-1

Barkham M, Hardy GE, Startupm M. (1998). The IIP32: A short version of the Inventory of Interpersonal Prob- lems. British Joumal of Clinical Psychology, 35(1): 21-35. doi: org/ 10.1111/j.2044-8260.1996.tb01159.x

Bolat N, Yavuz M, Eliaçik K, Zorlu A. (2017). The relationships between problematic intemet use, alexithymia levels and attachment characteristics in a sample of adolescents in a high school, Turkey. Psychology, Health \& Medicine, 23(5): 604-611. doi: 10.1080/13548506. 2017.1394474

Carbal L, Daurat j, Oliverira A, Neves L, Fonseca M, Marques S. (2016). Impact of intemet addiction on mental health of college students from central area of Portugal. Aten primaria, 48(1): 253-258. doi: 10.21125/inted.2017.1957

Chen Q, Quan X, Lu H, Fei P, Li M. (2015). Comparison of the personality and othr psychological factors of students with intemet addiction who do and do not have associated social dysfunction. Shanghai Archives of Psychiatry, 27(1): 36-41. doi: 10.11919/j.issn.1002-0829. 214129

Chen YL, Chen SH, Gau SS. (2015). ADHD and autistic traits, family function, parenting style, and social adjustment for Internet addiction among children and sdolescents in Taiwan: a longitudinal study. Research in developmental disabilities, 39: 20-31. doi: 10.1016/j.ridd. 2014.12.025

Dong G, Potenza MN. (2014). A cognitive-behavioral model of Intemet gaming disorder: Theoretical underpinnings and clinical implications. Journal of Psychiatric Research, 58: 7-11. doi: 10.1016/j.jpsychires.2014.07.005

$$
\begin{aligned}
& \text { واسطه تأثير داشت. با توجه به يافتهاى يزوهش حاضر }
\end{aligned}
$$

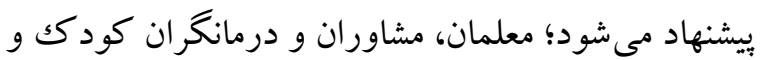

$$
\begin{aligned}
& \text { نوجوان در جهت شناسايى نوجوانان در معرض خطر } \\
& \text { اعتياد به اينترنت و افزايش بهزيستى آنها از يافتهاى اين } \\
& \text { يُزوهش استفاده كنند. اين مطالعه مانند ساير بُزوهشهاى } \\
& \text { علوم انسانى با محدوديتهايى مواجه بود، از جمله عدم } \\
& \text { همسانسازى آزمودنى ها بر اساس متغيرهاى مداخله كرى } \\
& \text { جون سطح فرهنگى خانواده و ساير متغيرهاى جمعيت- } \\
& \text { شناختى مى تواند به عنوان محدوديت به شمار رود. تنها } \\
& \text { ابزار جمع آورى اطلاعات در يزوهش حاضر يرسشنامه } \\
& \text { بود كه جنبه خود گزارشى دارد؛ بنابر اين خالى از اشكال و }
\end{aligned}
$$

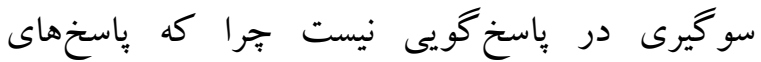

$$
\begin{aligned}
& \text { آزمودنى ها را تحت تأثير مطلوبيت اجتماعى با خطا مواجه }
\end{aligned}
$$

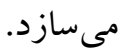

$$
\begin{aligned}
& \text { سياسگز ارى } \\
& \text { اين مقاله بركرفته از رساله دوره دكتراى روانشياسى } \\
& \text { تربيتى دانشگاه آزاد اسلامى واحد علوم و تحقيقات تهران } \\
& \text { است. نويسند كان بر خود لازم مىدانند از معاونت محترم } \\
& \text { بزّوهشى و تمامى آزمودنىهاى گر امى تشكر و قدردانى } \\
& \text { نمايند. }
\end{aligned}
$$

\section{References}

Adams AB. (2015). Developing Executive Functions through Mindfulness Training in SchoolAged Children. Philadelphia College of Osteopathic

Medicine.

doi: 10.3389/fpsyg.2019.02052

Alavi S, Jannatifard F, Slami M, Rezapoor H. (2011). Evaluation of DSM-IV-TR Diagnostic Criteria for Diagnosis of Intemet Addiction Disorder. Zahedan Journal of Research in Medical Sciences,13(6): 31-35. [Persian]. 
Gao T, Li J, Zhang H, Gao J, Kong Y, Hu Y, Mei S. (2018). The influence of alexithymia on mobile phone addiction: The role of depression, anxiety and stress. Joumal of Affective Disorders, 225: 761-766. doi: 10.1016/j.jad.2017.08.020

Koc M. (2011). Intemet addiction and psychopathology. The Turkish online Joumal of Educatiofiles: A behavior sampling analysis on Intemet addiction. Cyberpsynal Technology, 10(1): 143-148. doi: 10.17795/semj41149

Leyland A, Emerson LM, Rowse G. (2018). Testing for an Effect of a Mindfulness Induction on Child Executive Functions. Mindfulness, 9: 19. doi: 10.1007/s12671-018-0923-2

Luu K, Hall PA. (2017). Examining the Acute Effects of Hatha Yoga and Mindfulness Meditation on Executive Function and Mood. Mindfulness, 8(4): 873-880. doi: 10.1007/ s12671-016-0661-2

Mahdavi E, Manshaie G. (2016). Comparison of mood swings and emotional expression in patients with coronary heart disease and healthy individuals. Joumal of Fayz, 20(3): 260-266. [Persian].

Moreau A, Laconi S, Delfour M, Chabrol H. (2015). Psychopathological profiles of adolescent and young adult problematic Facebook users. Computers in Human Behavior, 44: 64-69. doi.org/10.1016/j.chb.2014.11.045

Nejati V. (2013). Cognitive Ability Questionnaire: Design and Evaluation of Psychometric Properties. Journal of Cognitive Science, 5(2): 11-19. [Persian].

Noone C, Bunting B, Hogan MJ. (2016). Does mindfulness enhance critical thinking? Evidence for the mediating effects of executive functioning in the relationship between mindfulness and critical thinking. Frontiers in psychology, 6: 2043. doi: 10.3389/fpsyg.2015.02043

Rastghar S, Abdallahi MH, Shadgholiyan M. (2014). Internet addiction, social intimacy and happiness among students. Joumal of
Transformational Psychology: Iranian Psychologists, 11(42): 159-168. [Persian].

Sariyska R, Lachmann B., Markett S, Reuter M, Montag C. (2017). Individual differences in implicit leaming abilities and impulsive behavior in the context of Intemet addiction and Internet Gaming Disorder under the consideration of gender. Addictive Behaviors Reports, 5: 19-28. doi: 10.1016/j.abrep.2017.02.00

Schimmenti A, Passanisi A, Caretti V, Marca LL, Granieri A, Iacolino C, Gervasi AM, Maganuco NR, Billieux J. (2017). Traumatic experiences, alexithymia, and Intemet addiction symptoms among late adolescents: A moderated mediation analysis. Addictive Behaviors, 64: 314-320. doi: 10.1016/j.addbeh.2015.11.002

Spensieri V, Valastro C, Cenutti R. (2016). PO-31: technology addiction and alexithymia features in a sample of Italian adolescents. Journal of Behavioral Addictions, 5(1): 58-59. doi: 10.32598/ajnpp.5.1.120

Tang JH, Chen MC, Yang CY, Chung TY, Lee YA. (2016). Personality traits, interpersonal relationships, online social support, and Facebook addiction. Telematics and Informatics, 33(1): 102-108. doi: org/10.1016/j.tele.2015.06.003

Tosifiyan N, Ghaderi K, Mahmoudi A, Khalediyan M. (2017). Structural Modeling of Early Maladaptive Schemas and Executive Functions of Patients with Multiple Sclerosis with Emphasis on the Mediating Role of Loneliness. Journal of Neurology Psychology, 3(3): 93-108.16. [Persian].

Tripathi A. (2017). Impact of intemet addiction omn mental health:an integrative therapy us needed. Integr Med int, 4: 215-222. doi: org/10.1159/000491997

Valls-Serrano C, Caracuel A, Verdejo-Garcia A. (2016). Goal management training and mindfulness meditation improve executive functions and transfer to ecological tasks of daily life in polysubstance users enrolled in therapeutic community treatment. Drug and 
alcohol dependence, 165: 9-14. doi: 10.1016/j.drugalcdep.2016.04.040

Wu JYW, Ko HC, Wong TY, Wu LA, Oei TP. (2016). Positive outcome expectancy mediates the relationship between peer influence and Internet gaming addiction among adolescents in Taiwan. Cyberpsychology, Behavior and Social Networking, 19(1): 49-55. doi: 10. 1089/cyber.2015.0345

Young KS. (1996). Internet Addiction: Symptoms, Evaluation, and Treatment'. reproduced from Vande Creel L, Jackson TL. (1999) 'Innovations in Clinical Practice' Professional Resource Press. 10.1177/0002764204270278
Zhou Z, Li C, Zhu H. (2013). An error-related negativity potential investigation of response monitoring function in individuals with intemet addiction disorder. Front Behav Neurosci, 7 : 131. doi: 10.3389/fnbeh.2013.00131

Zonglin D, Xiaoliang G, Jingyu Sh, Hosameldin OA, Ahmed Asoke KN. (2019). Internet Addiction Disorder Detection of Chinese College Students Using Several Personality Questionnaire Data and Support Vector Machine. Addictive Behaviors Reports. doi: org/10.1016/j.abrep. 2019.100200

\section{يوستها}

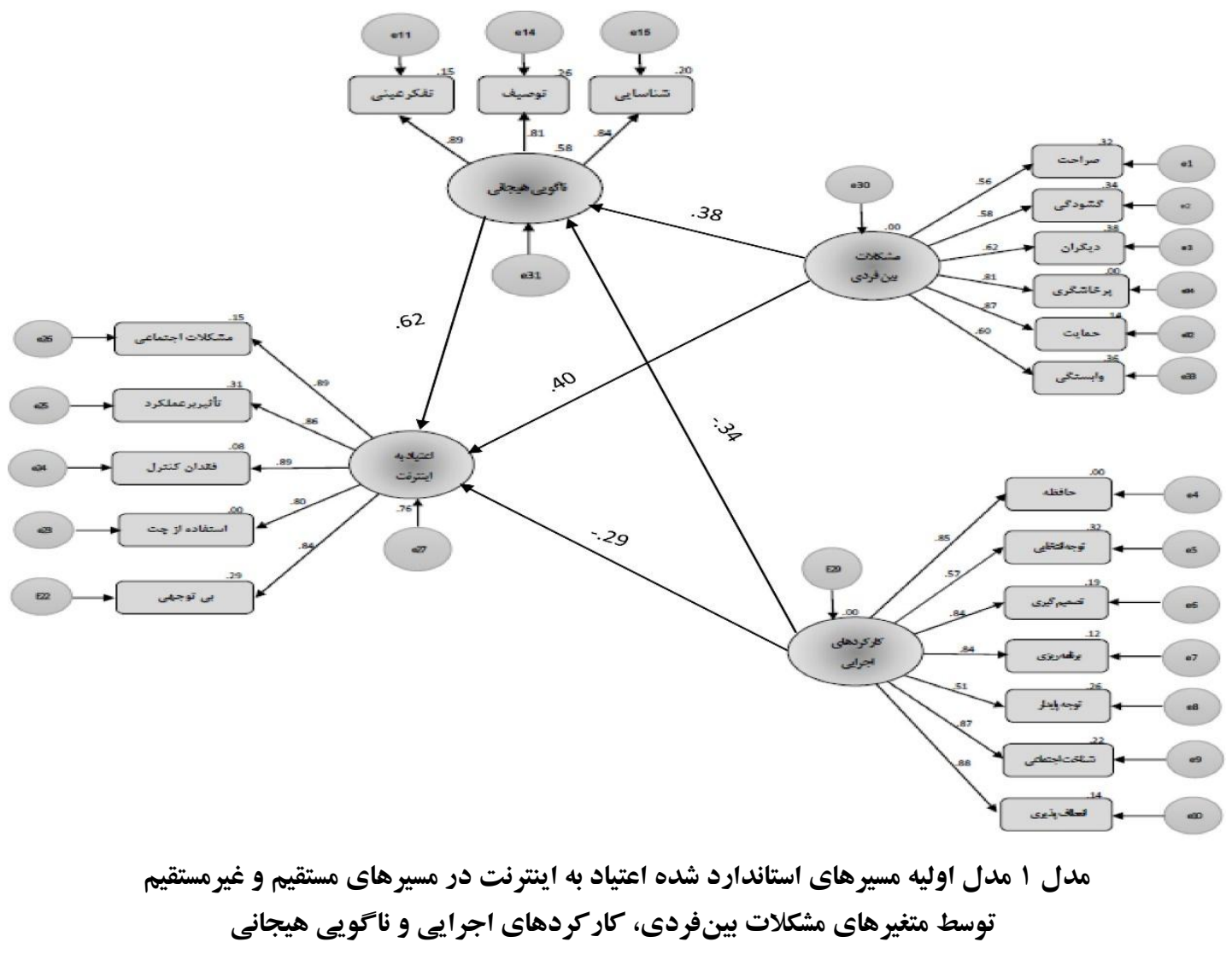




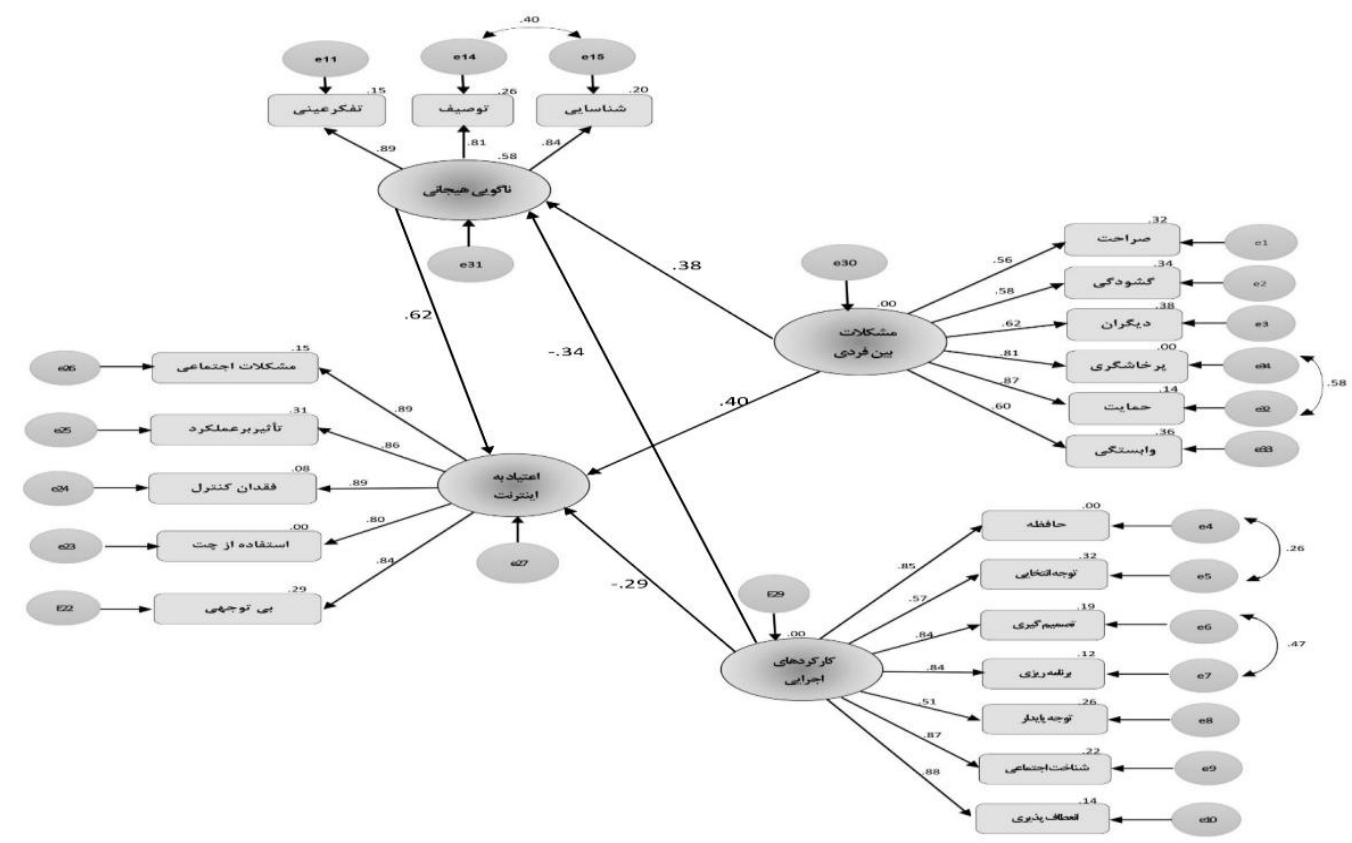

مدل r مدل نهايى مسير هاى آزمون شده به همراه آمارههاى بيشيشينى اعتياد به اينترنت در مسيرهاى مستقيم

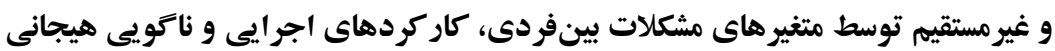

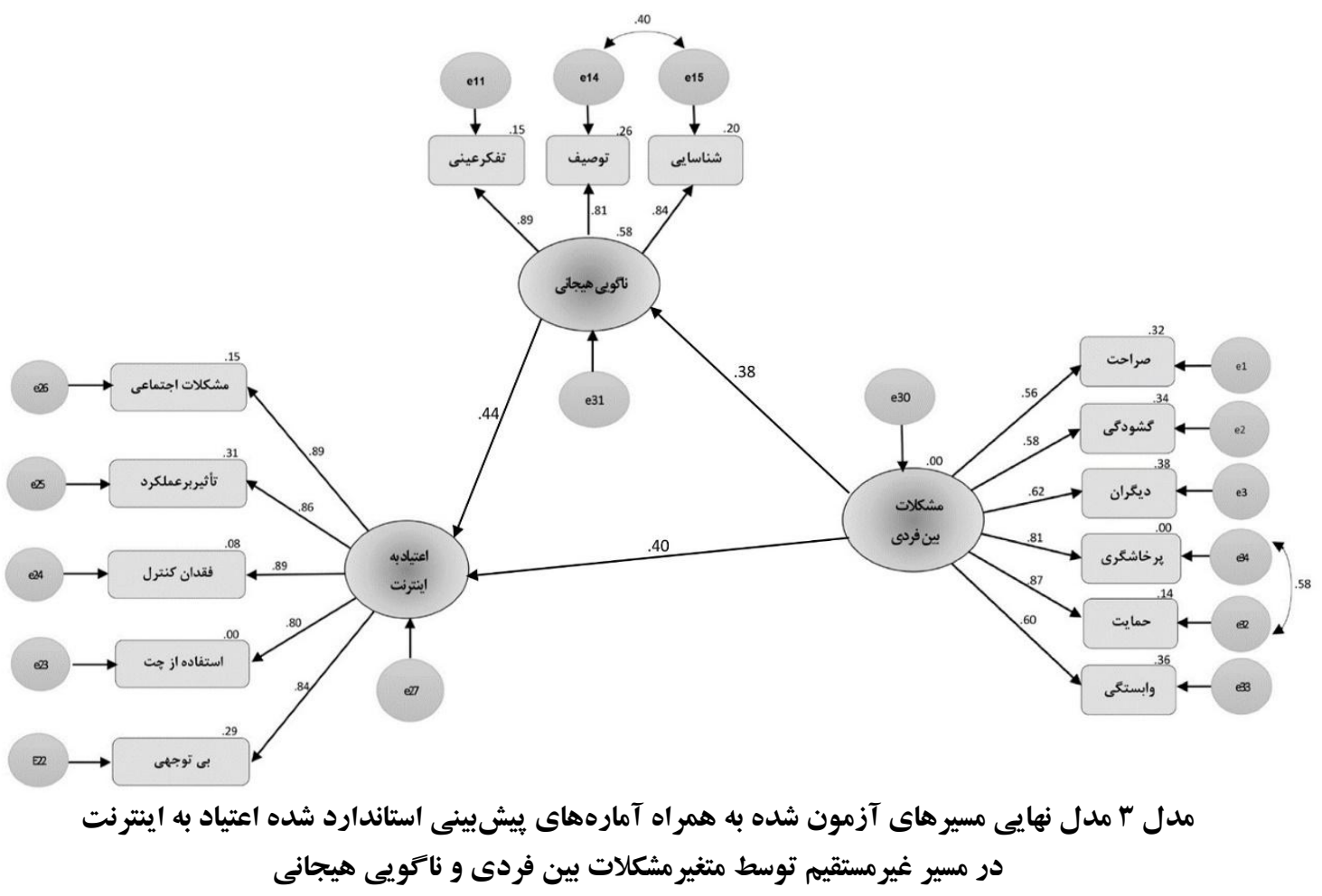

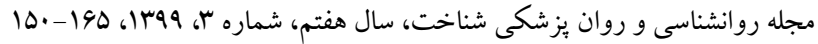




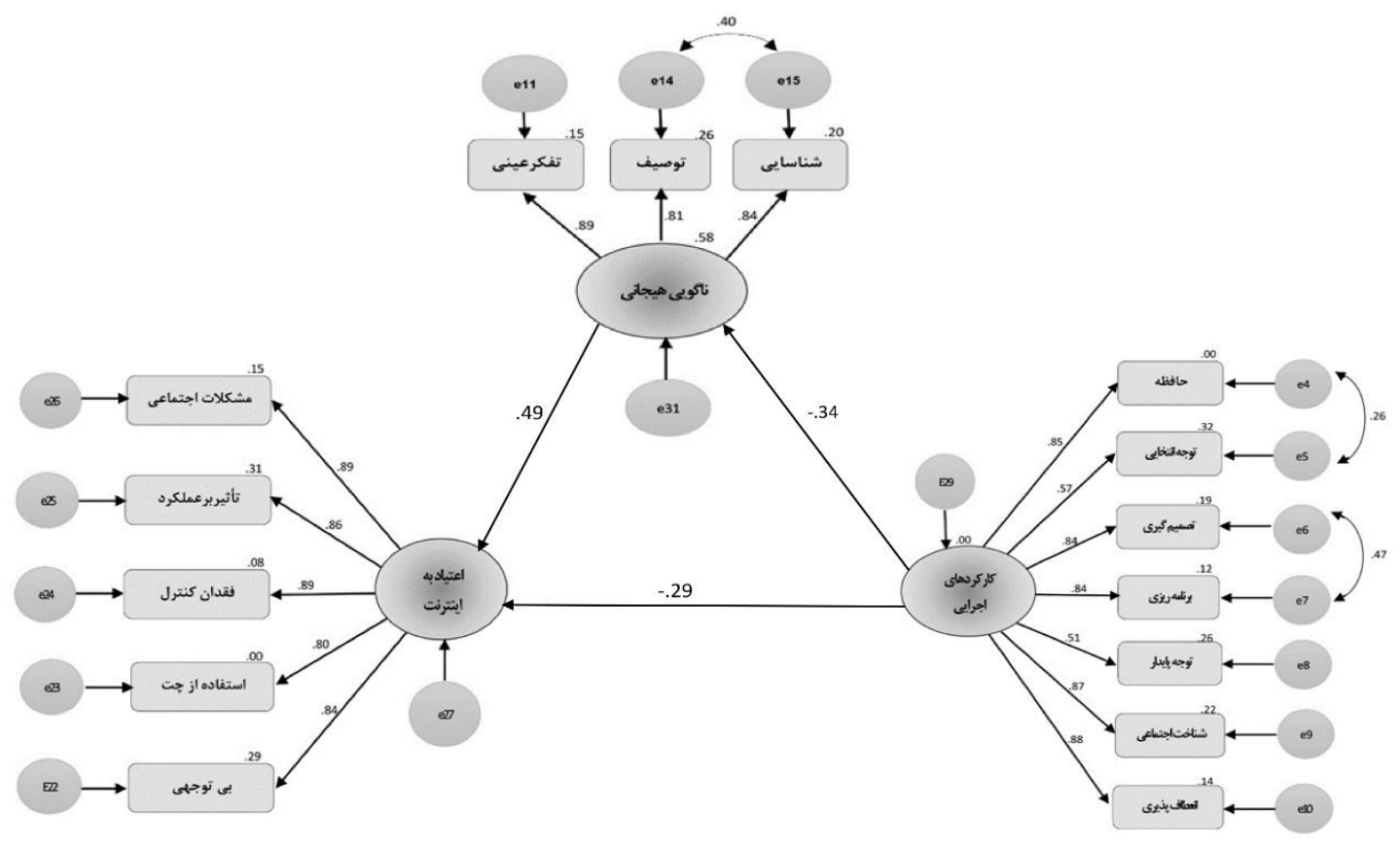

مدل F مدل نهايع مسيرهاى آزمون شده به همراه آمارههاى بيشينى استاندارد شده اعتياد به اينترنت

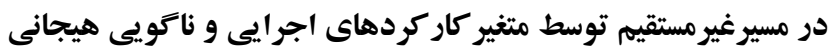

